\title{
Singpuria, a new genus of Eudicot flower from the latest Cretaceous Deccan Intertrappean Beds of India
}

\author{
DEEPAK RAMTEKE ${ }^{1}$, STEVEN R. MANCHESTER ${ }^{2 *}$, VAISHALI D. NAGRALE ${ }^{3}$ \\ and SELENA Y. SMITH ${ }^{4}$ \\ ${ }^{1}$ Gondia Education Society High School and Junior College, Mohadi. Dist., Gondia, 4416014-M.S., India; \\ e-mail: deeplifesc@gmail.com \\ ${ }^{2}$ Florida Museum of Natural History, University of Florida, Gainesville, Florida, 32611-7800, USA; \\ e-mail: steven@flmnh.ufl.edu \\ ${ }^{3}$ Block Resource Center, P.S. Sakoli, Dist., Bhandara, 441802, M.S. India; e-mail: vaishalidnagrale@gmail.com \\ ${ }^{4}$ Department of Earth \& Environmental Sciences and Museum of Paleontology, University of Michigan, \\ Ann Arbor, MI, 48019, USA; e-mail: sysmith@umich.edu
}

Received 25 February 2020; accepted for publication 6 November 2020

\begin{abstract}
A new bisexual flower, Singpuria kapgatei, gen. et sp. nov., is described from chert of latest Cretaceous age from the Deccan Intertrappean Beds at Singpur, Madhya Pradesh, in central India. The hypogynous, actinomorphic flower is $\sim 1.6 \mathrm{~mm}$ wide, with distinct sepals and petals. The androecium consists of 18 tetrasporangiate, dithecal, basifixed anthers borne in radial pairs on nine bifurcate filaments. The gynoecium is superior and syncarpous, with pentagonal symmetry. Pollen from the stamens is tricolporate and microreticulate. The combined morphological features of this flower indicate that Singpuria is a eudicot with affinities in the Pentapetalae, but we have been unable to make a more precise assignment. Nevertheless, we consider it useful to place this rare fossil flower on record as an exemplary extinct member of the Deccan biota. Singpuria may represent a clade that was isolated on the Indian subcontinent and became extinct in response to environmental changes at the $\mathrm{K} / \mathrm{Pg}$ boundary, or later in the Cenozoic as the land mass moved northward through new climate zones and collided with Eurasia.
\end{abstract}

KEYWORDS: Deccan chert, Singpur, paleobotany, bifurcate stamens, tricolporate microreticulate pollen

\section{INTRODUCTION}

Fossil plants preserved in the Deccan Intertrappean Beds of central India provide insights into the biota that inhabited the Indian subcontinent when it was isolated from other major land masses in the late Cretaceous and early Cenozoic. The late Maastrichtian to Paleocene flora of the Deccan Intertrappean Beds is rich in silicified woods, fruits and seeds (reviewed, Kapgate, 2005; Smith et al., 2015; Wheeler et al., 2017) but the flowers that have been recovered are low in diversity. The myrtalean

\footnotetext{
Corresponding author
}

flower Sahnianthus Shukla (1944; syn. Chitaleypushpam Paradkar, Deccananthus Chitaley et Kate, Flosfemina Kar, Ambwani, A. Sahni et Sharma, Lythraceopushpam Narkhede, Bhowal et Meshram, Raoanthus Chitaley et Patel) is an exception, being common at several (at least seven) localities and in various states of maturation. Very small flowers (1.0 to $1.5 \mathrm{~mm}$ diameter) include those described as Chenopodianthus VD Kapgate, DK Kapgate et Sheikh (2006), Tetraplasandranthus VD Kapgate, DK Kapgate et Sheikh (2009) and Flosvirulus Kar, Ambwani, A. Sahni et 
Sharma (2003) from the classic locality of Mohgaonkalan. Here we recognize a new kind of flower with intact stamens and pollen from a site near Singpur, northeast of Nagpur in central India.

The late Maastrichtian Singpur locality is well known for its flora preserved in chert, including pollen and spores (Samant et al., 2008) and fruits and seeds, such as Baccatocarpon Bhowal et Sheikh (2004; Manchester et al., 2019), Drupaceocarpon Nandeshwar et Narkhede (2016), Pantocarpon Kapgate, Patil, Ilamkar et Ramteke (Kapgate et al., 2007; Manchester et al., 2020; syn. Verbenaceocarpon Dhabarde, Sheikh, et Kolhe), Phyllanthocarpon Mistri, Kapgate et Sheikh ex Kapgate et Manchester (Kapgate et al., 2017), Ramakonospermus Matin et Juneja (Sheikh and Bhowal, 2003), Singhpurospermum Nandeshwar et Narkhede (2017) and Viracarpon Sahni (Matsunaga et al., 2018). In addition, we have recognized specimens of Enigmocarpon Sahni and Graminocarpon Chitaley et Sheikh in collections from this site, supplementary to the original occurrence reports of these taxa from Mohgaonkalan (Sahni, 1943; Chitaley and Sheikh, 1971), a paleobotanically rich site $64 \mathrm{~km}$ northeast of Singpur.

The new permineralized flower presented here adds to the diversity of angiosperms known from the Deccan Intertrappean Beds. Analysis of successive serial peels facilitated three-dimensional (3-D) conceptualization of the specimen, and an examination of pollen within the anthers by light and scanning electron microscopy yielded additional characters. Here we document the morphology and consider its systematic placement among eudicot angiosperms.

\section{MATERIAL AND METHODS}

The flower was discovered in a piece of black chert collected from the edge of a farming field near Singpur (alternate spelling Singhpur), $\sim 65 \mathrm{~km} \mathrm{NNW}$ of Nagpur in Chhindwara District, Madhya Pradesh, India $\left(21^{\circ} 36.958^{\prime} \mathrm{N}, 78^{\circ} 43.827^{\prime} \mathrm{E}\right)$. The Singpur locality is interpreted to be latest Maastrichtian, based on stratigraphic correlations of pollen (Samant et al., 2008) and megafossils (Smith et al., 2015).

The flower was exposed in a natural fracture of the chert and was serially sectioned by the acetate peel method. Successive cellulose acetate peels were prepared by etching first with hydrofluoric acid, washing in water, squirting acetone across the etched surface, and carefully applying an acetate sheet to bond with the etched surface. When dry, the peels were detached, cut with scissors, mounted on glass slides and covered by a glass coverslip affixed with Canada balsam. The peels were photographed on a Nikon Labophot microscope and imported to Avizo 9.0 Lite (FEI Visualization Science Group, Bordeaux, France) for alignment and $3-\mathrm{D}$ reconstruction. Succesive peel images and a slice movie of the holotype are accessible at Morphosource.org (key word = Singpuria).

Pollen was studied and photographed by transmitted light microscopy of the peels with a Nikon Eclipse compound microscope. In addition, one of the peels was cleaned in hydrofluoric acid, mounted on an aluminum stub (etched surface upward) and analyzed with a Hitachi SU5000 field-emission scanning electron microscope (SEM) at the Interdisciplinary Center for Biotechnology Research at the University of Florida.

The floral diagram was generated with automatic rendering from http://kvetnidiagram.8u.cz/index en.php (Kebert, 2014-2020). In attempting to place the flower systematically, we entered morphological characters of the fossil into the web-based key, The Families of Angiosperms (Watson and Dallwitz, 1992 onwards), to obtain lists of extant families conforming to those characters, and considered each of those results in light of additional characters not available in the key program. Additional floral features were investigated with reference to those described in the The Families and Genera of Flowering Plants (e.g. Bayer, 2003; Bayer and Kubitzki, 2003; Anderberg, 2004; Fritsch, 2004; Stevens, 2004; Stevens et al., 2004a,b; Horn, 2007; Daly et al., 2011; Kubitzki et al., 2011; Pell et al., 2011) and other literature. Pollen was compared with that of extant taxa treated in systematic literature as cited, and with reference to the SEM survey of Li et al. (2010). Terminology for pollen follows Halbritter et al. (2018).

\section{SYSTEMATICS}

\author{
Clade. Pentapetalae
}

Family. Incertae Sedis

Genus. Singpuria

Ramteke, Manchester, et Nagrale gen. nov. Pls. 1, 2

Etymology. The generic name refers to the town of Singpur (also known as Singhpur), close to the location where this fossil was collected.

Type species. Singpuria kapgatei Ramteke, Manchester et Nagrale sp. nov.

Plant Fossil Names Registry.PFN001778 (for new genus). 
Species: Singpuria kapgatei Ramteke, Manchester et Nagrale sp. nov.

Etymology. The specific epithet honors Prof. Dashrath K. Kapgate, whose research and mentorship have greatly improved our knowledge of the Deccan Intertrappean flora.

\section{Holoty pe. UF19278-62141.}

Repository. Paleobotanical Collection, Florida Museum of Natural History, University of Florida, Gainesville, Florida, USA

Type locality. Singpur, Madhya Pradesh, India; Late Maastrichtian.

Plant Fossil Names Registry.PFN001779 (for new species).

Generic and specific diagnosis. Flower bisexual, actinomorphic, perianth in two whorls, petals imbricate, merosity estimated at 5, imbricate, sepals imbricate. Androecium of 9 stamens with basally bifurcate filaments and 18 anthers. Anthers tetrasporangiate, dithecal, basifixed, opening by longitudinal slits. Each anther of outer whorl connected by bifurcate filament to an anther of inner whorl. Pollen tricolporate, prolate, psilate by LM, finely punctate by SEM. Gynoecium pentacarpellate; style pentagonal in cross section, ovary circular in cross section, with 10 radial ribs in upper half.

Description. The flower is actinomorphic, hermaphroditic, and is $\sim 1.6 \mathrm{~mm}$ in diameter at the level of style and stamens. The perianth is not completely preserved, but enough is present to establish that there are two whorls (Pl. 1, figs $4,6)$. The inner perianth whorl is represented by portions of three adjacent petals that have their edges overlapping in an imbricate organization (Pl. 1, figs 12, 13). Although the apical extremities of the petals are not known, at the level of style and anthers they are $0.1 \mathrm{~mm}$ thick and $1.0 \mathrm{~mm}$ wide. From the geometry, five petals can be inferred. Only one sepal is clearly preserved, but its size $(0.6 \mathrm{~mm}$ wide, $0.19 \mathrm{~mm}$ thick) and shape indicate that there were likely five sepals, although this remains uncertain. The anthers are arranged in two whorls of nine each (Pl. 1, figs 1-5). The stamens are in a distinctive paired arrangement with only nine filaments at the base, each of which bifurcates dorsiventrally ( $\mathrm{Pl}$. 1, figs 5, 6) to connect with a radial pair of anthers, one in the outer whorl and the other in the inner whorl. Thus, while there are 18 anthers in total, each dorsiventral pair shares a common filament. The anthers are $0.3 \mathrm{~mm}$ wide and $1.9 \mathrm{~mm}$ deep, with four pollen sacs dehiscing by longitudinal slits, attached to a connective that is 0.12 to $0.15 \mathrm{~mm}$ in diameter (Pl. 1, figs 13, 14; Pl. 2 figs 1, 2). Successive serial peels reveal that the anthers are basifixed (Pl. 1, figs 4,5 ). The pollen grains are prolate, elongate, 32-35 $\mu \mathrm{m}$ long, $19-23 \mu \mathrm{m}$ in equatorial diameter, tapered at the poles, and tricolporate (Pl. 2, figs $2-5$ ). They are psilate by LM (Pl. 2, fig. 2), with microreticulate ornamentation visible at higher magnification by SEM (Pl. 2, fig. 5). The style is $\sim 0.2 \mathrm{~mm}$ in diameter and pentagonal in cross section (Pl. 1, figs $13,14)$, suggesting a pentamerous gynoecium. The apical-most part of the flower is missing, so we were unable to observe whether there is a single stigma or more. The ovary is circular in cross section and $\sim 0.52 \mathrm{~mm}$ in diameter. The apical portion of the ovary has ten equally spaced vertical ribs (Pl. 1, figs 6,7$)$ but the lower portion is smooth (Pl. 1, figs 8, 9). The ovary content is not well preserved; hence the number of locules, placentation type and ovule condition are unknown.

\section{DISCUSSION}

The arrangement of the perianth, androecium and gynoecium for Singpuria kapgateii is summarized in the floral diagram (Fig. 1). Although the perianth is incompletely preserved, enough is present to establish that there clearly are two whorls, and from the symmetry of those petals and sepals that are present we infer five per cycle. The edges of the petals overlap, indicating imbricate rather than valvate aestivation. The androecium, with 18 anthers joined in radial pairs on nine bifurcate filaments, is distinctive. This arrangement is seen by studying the positions of each radial pair of anthers and their filaments through successive transverse peels (Pl. 1, figs 1-6). Because only one specimen is available, we do not know if the number of stamens was fixed or variable in the species. The gynoecium is syncarpous, and is inferred to be pentamerous because the style base is pentagonal. However, the upper part of the ovary has ten equally prominent radial ribs, so 


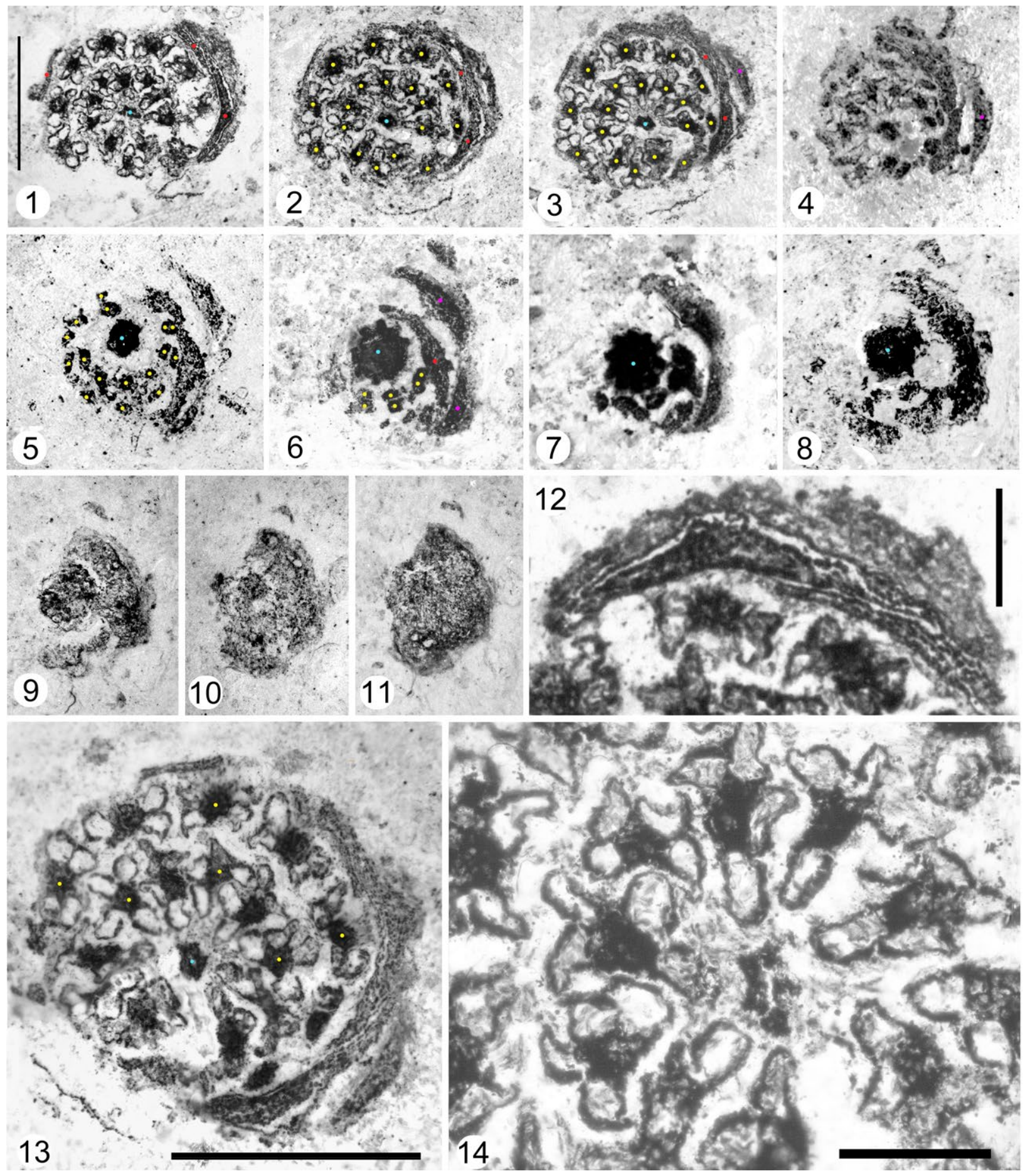

Plate 1. Floral morphology of Singpuria kapgatei gen. et sp. nov. Holotype, UF19278-62141. 1-11. descending serial sections of the flower. Colored dots indicate different floral parts: blue = gynoecium, yellow = anthers, red = corolla, violet $=$ calyx; 1-4. sections showing remnants of perianth and 18 anthers in two whorls surrounding a single style; $\mathbf{5}$. section at level showing bifurcate stamen filaments (paired filaments above the bifurcation, single filaments below the bifurcation), and widened base of the style; 6, 7. dorsiventral pairs of stamen filaments coalescing; apical part of ovary with ten ribs; 8-11. successive sections of lower part of flower, showing base of perianth and receptacle; 12. enlargement from fig. 1, showing imbricate perianth members; 13. enlargement showing the anthers, with alternate pairs of anthers color-coded, with yellow dots showing their radial arrangement. Style indicated by blue dot; 14. detail of inner whorl of anthers and central pentagonal style. Scale bars: 1 (applies also to $2-11$ ) and $13=1 \mathrm{~mm} ; 12,14=0.25 \mathrm{~mm}$

there is an alternate possibility that the flower bore ten carpels. The internal structure of the gynoecium is unknown because the base is not fully preserved. Hence the ovary content and the placentation type are unknown.
Affinities. Pollen recovered from the anthers of Singpuria differ from the dispersed pollen types so far recorded from Singpur (Samant et al., 2008). Also, we were unable to link this flower directly with any of the 

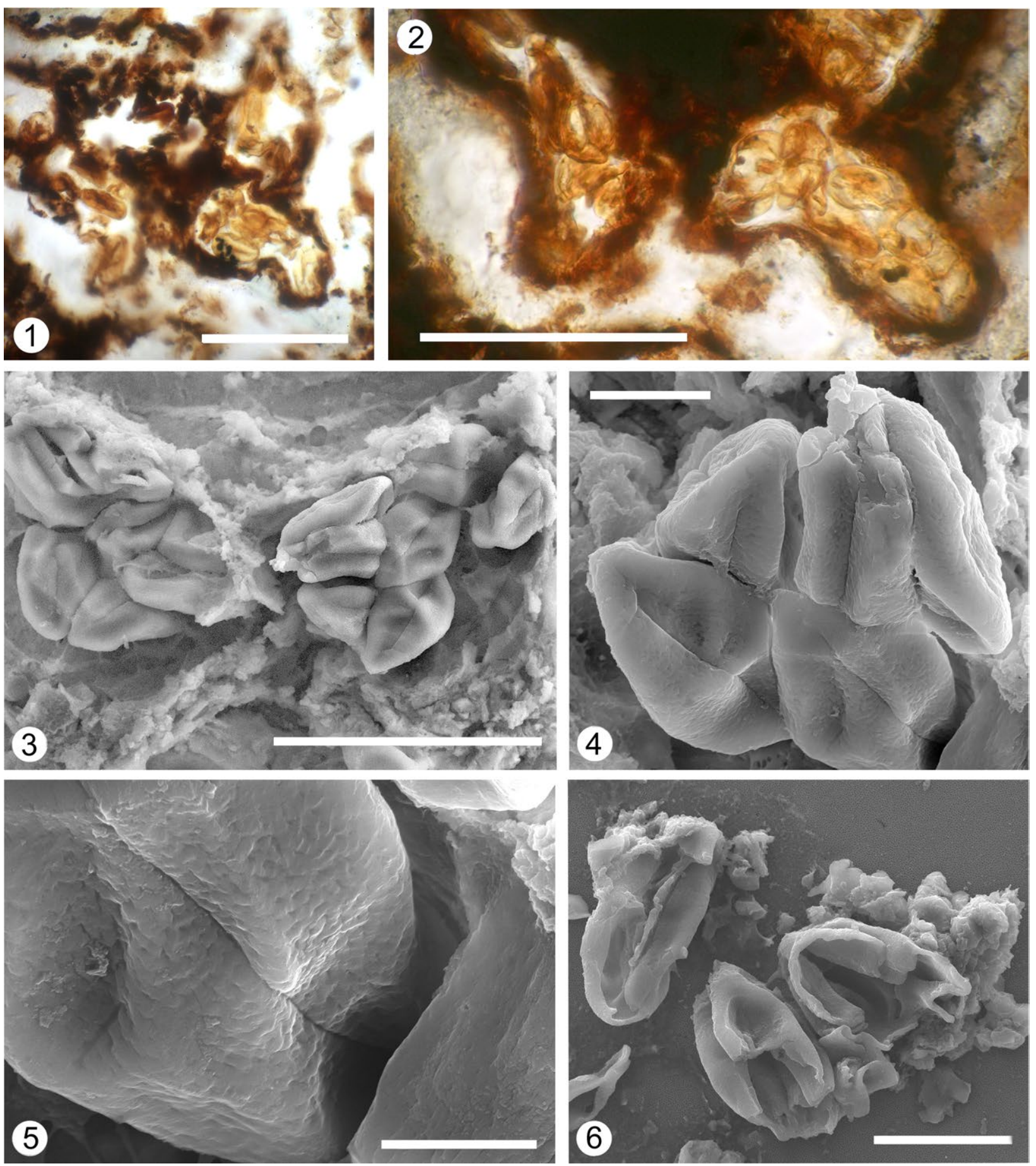

Plate 2. Singpuria kapgatei androecium and pollen. 1, 2. anther in transverse section, showing in situ prolate tricolporate pollen grains; 3-5. clumps of tricolporate pollen in situ, SEM; 6. broken pollen grains, showing endoaperture and thin exine; Scale bars: $1,2=0.1 \mathrm{~mm} ; 3=50 \mu \mathrm{m} ; 4=10 \mu \mathrm{m} ; 5=5 \mu \mathrm{m} ; 6=2 \mu \mathrm{m}$

fruits known from Singpur or other Deccan Intertrappean Beds. The presence of ten ribs on the apical part of the gynoecium (Pl. 1, fig. 7) leads us to hypothesize that the fruit that developed from this species of flower may have been ten-carpellate. The extinct fruit genus Daberocarpon Chitaley et Sheikh (Malvaceae: Malvoideae) has ten-loculed capsules (Chitaley and Sheikh, 1973) but it would be expected to associate be associated with spiny porate pollen characteristic of Malvoideae rather than with the smooth tricoporate pollen produced by Singpuria.

The perianth of Singpuria, differentiated into sepals and petals, and the tricolporate pollen, are features diagnostic of eudicots (Ronse de Craene, 2010). We attempted to key out this flower to the family level by seeking those taxa possessing the following suite of characters available in the database of Watson and 


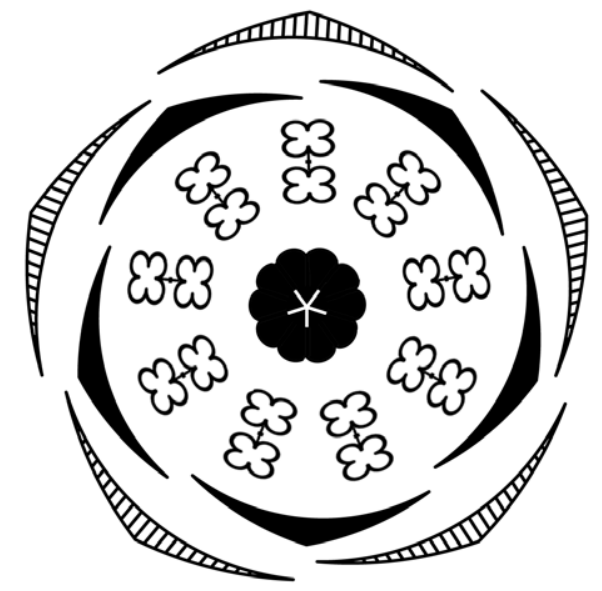

Fig. 1. Floral diagram for Singpuria, showing two imbricate whorls of perianth, 18 anthers, and 10-ribbed ovary

Dallwitz (1992 onwards): flowers actinomorphic, corolla five-lobed, imbricate, stamens nine, filantherous, anthers basifixed, dehiscing via longitudinal slits, pollen shed as single grains, tricolporate, gynoecium superior, syncarpous, composed of five carpels, and having a single style. A second keying attempt used the same features, with the exception of carpel number being indicated as ten rather than five, because it is uncertain whether the ten ribs on the upper part of the ovary each were distributed one or two per carpel. As an alternative to the specification of nine stamens (interpreting each filament base as one stamen), we also entered 18 stamens (the number of anthers). The 27 resulting families (26 when Tiliaceae and Malvaceae s.s. are treated together as Malvaceae s.l.) from these keying runs, shown in Table 1, all belong to the Pentapetalae (Chanderbali et al., 2017; Judd et al. 2016).

Based on characters included in the keying exercise summarized above, Singpuria has similarities with the core eudicot family Dilleniaceae (sensu Soltis et al., 2018) as well as 25 families of Rosids and Asterids (Tab. 1). The fossil differs from Dilleniaceae by its syncarpy, however, contrasting with the apocarpous to hemisyncarpous condition characteristic of that family (Horn, 2007). The Rosid families retrieved in the keying exercise included Anacardiaceae, Burseraceae, Cistaceae, Guttiferae, Humiriaceae, Irvingiaceae, Malvaceae, Muntingiaceae, Ochnaceae, Paracryphiaceae, Pentadiplandraceae, Rutaceae, Salicaceae, Sapindaceae and Zygophyllaceae. Ten Asterid families were recovered, including Aizoaceae, Aquifoliaceae, Ericaceae, Lennoaceae (Boraginaceae), Marcgraviaceae, Primulaceae,
Sarrraceniaceae, Sapotaceae, Scytopetalaceae (Lecythidiaceae), Styracaceae and Theaceae. Each of these families differs in a number of traits from the fossil (Tab. 1).

Some pollen features not included in the Watson and Dallwitz (1992 onwards) key, such as shape and ornamentation, rule out affinities of Singpuria with these families (Tab. 1). The monad pollen of Singpuria is clearly distinct from the permanent tetrads typical of Ericaceae (Stevens et al., 2004b; Hofmann, 2018) and from Sarraceniaceae, which is usually four-colpate or more (Oswald et al., 2011; Thanikaimoni and Vasanthy, 1972). We can also rule out affinities with Aizoaceae, Aquifoliaceae and Malvaceae subf. Malvoideae by their ornamentation being scabrate, clavate and spinulate, respectively, rather than microreticulate as in Singpuria (see references in Tab. 1). Most of the other families listed in Table 1 include taxa with pollen that, at least in some genera, is tricolporate and microreticulate like Singpuria. However, whereas the colpus membrane of Singpuria is smooth (Pl. 2, fig. 4), it is granular in Dilleniaceae, Burseraceae, Clusiaceae, Humiriaceae, Marcgraviaceae and Sapindaceae. The pollen grains of Singpuria are markedly narrowed toward each pole, rather than smoothly rounded as in Sapotaceae, Burseraceae and most Malvaceae. The unique structure of the androecium of Singpuria with its bifurcate stamens and radial alignment of the two whorls of anthers distinguishes the fossil from extant genera in all of these families.

Conclusion. Recognition of this new kind of flower increases the diversity of taxa known from the Deccan Intertrappean cherts. After comprehensive comparative work, it might seem frustrating that the well-preserved features of this flower do not lead us to a precise systematic assignment with respect to modern angiosperm families. However, we cannot expect late Cretaceous plants always to conform to extant families. We conclude that Singpuria kapgatei likely represents an extinct family, but with only one specimen available, and lacking additional details of the gynoecium, we refrain from proposing a new family name. If Singpuria represents a clade that was isolated on the Indian subcontinent, it could have become extinct in response to the Deccan volcanism and environmental changes at the $\mathrm{K} / \mathrm{Pg}$ boundary (e.g. Sprain et al., 2019), or later as the land mass 
Table 1. List of families compared with Singpuria, based on results from The Families of Angiosperms key (Watson and Dallwitz, 1992 onwards)

\begin{tabular}{|c|c|c|c|c|c|}
\hline & Affinity & Carpel number & $\begin{array}{l}\text { Stamen } \\
\text { number }\end{array}$ & Pollen ornamentation & $\begin{array}{l}\text { Morphological } \\
\text { differences }\end{array}$ \\
\hline Singpuria gen. nov. & Pentapetalae & 10 (or $5 ?$ ) & $\begin{array}{l}18 \text { anthers; } \\
9 \text { filaments }\end{array}$ & $\begin{array}{l}\text { Microreticulate, colpus } \\
\text { membrane smooth }\end{array}$ & - \\
\hline Dilleniaceae & Dilleniales & $(1-) 2-7(-20)$ & $\begin{array}{l}1-10 \text { (rarely) } \\
\text { or } 15-150\end{array}$ & $\begin{array}{l}\text { Punctate to reticulate, col- } \\
\text { pus membrane granular } \\
\text { (Dickison et al., 1982) }\end{array}$ & $\begin{array}{l}\text { Apocarpous to hemi- } \\
\text { syncarpous gynoecium } \\
\text { (Horn, 2007); Colpus } \\
\text { membrane granular }\end{array}$ \\
\hline Anacardiaceae & $\begin{array}{l}\text { Rosids } \\
\text { Sapindales }\end{array}$ & $1-12$ & $(1-) 5-10(-12)$ & $\begin{array}{l}\text { Striate to microreticulate } \\
\text { to reticulate } \\
\text { (Ibe and Leis, 1979) }\end{array}$ & (Pell et al., 2011) \\
\hline Burseraceae & $\begin{array}{l}\text { Rosids } \\
\text { Sapindales }\end{array}$ & $2-5(6-12)$ & $4-5$ or $8-10$ & $\begin{array}{l}\text { Diverse ornamentation } \\
\text { types, echinate when } \\
\text { microreticulate } \\
\text { (Harley et al., 2005) }\end{array}$ & $\begin{array}{l}\text { Sepals usually valvate } \\
\text { (Daly et al., 2011); } \\
\text { Colpus membrane } \\
\text { granular }\end{array}$ \\
\hline Cistaceae & $\begin{array}{l}\text { Rosids } \\
\text { Malvales }\end{array}$ & $\begin{array}{l}\text { (2)3-5(6-numer- } \\
\text { ous) }\end{array}$ & (3-)15-many & $\begin{array}{l}\text { Reticulate to finely reticu- } \\
\text { late (Ukraintseva, 1993; } \\
\text { Civeyrel et al., 2011) }\end{array}$ & $\begin{array}{l}\text { Stamens usu. numerous } \\
\text { (Arrington and Kubitzki, } \\
\text { 2003) }\end{array}$ \\
\hline Clusiaceae & $\begin{array}{l}\text { Rosids } \\
\text { Malphighiales }\end{array}$ & $\begin{array}{l}(1-) 3 \text { carpelled, } \\
\text { or } 5(-13)\end{array}$ & $\begin{array}{l}3-4 \text { (rarely), } \\
\text { or } 20-\text { many }\end{array}$ & $\begin{array}{l}\text { Variable incl. microre- } \\
\text { ticulate (Seetharam and } \\
\text { Maheshwari, 1986) }\end{array}$ & $\begin{array}{l}\text { Colpus membrane } \\
\text { granular }\end{array}$ \\
\hline Humiriaceae & $\begin{array}{l}\text { Rosids } \\
\text { Malphighiales }\end{array}$ & $(4-) 5(-8)$ & $10-100$ & $\begin{array}{l}\text { Microreticulate } \\
\text { (Bove and Melhem, 2000) }\end{array}$ & $\begin{array}{l}\text { Colpus membrane gran- } \\
\text { ular; grains suboblate to } \\
\text { subprolate }\end{array}$ \\
\hline Irvingiaceae & Rosids & $(4-) 5$, or 2 & $9-10$ & $\begin{array}{l}\text { Microreticulate to striate; } \\
\text { subglobose (Satabié, 1974) }\end{array}$ & $\begin{array}{l}\text { Intrastaminal nectary } \\
\text { disk }\end{array}$ \\
\hline $\begin{array}{l}\text { Malvoid } \\
\text { Malvaceae }\end{array}$ & $\begin{array}{l}\text { Rosids } \\
\text { Malvales }\end{array}$ & $6-14$ & $\begin{array}{l}5-15-50 \\
(-100)\end{array}$ & $\begin{array}{l}\text { Spheroidal, echinate } \\
\text { (Christensen, 1986) }\end{array}$ & $\begin{array}{l}\text { Spheroidal, echinate } \\
\text { exine, usually polypo- } \\
\text { rate; calyx gamosepal- } \\
\text { ous, valvate }\end{array}$ \\
\hline $\begin{array}{l}\text { Tilioid } \\
\text { Malvaceae }\end{array}$ & $\begin{array}{l}\text { Rosids } \\
\text { Malvales }\end{array}$ & $2-100$ & $(8-) 15-100$ & $\begin{array}{l}\text { Reticulate to micro-reticu- } \\
\text { late (Perveen et al., 2004) }\end{array}$ & $\begin{array}{l}\text { Stamens numerous, } \\
\text { sometimes fascicles of } 5 .\end{array}$ \\
\hline Muntingiaceae & $\begin{array}{l}\text { Rosids } \\
\text { Malvales }\end{array}$ & 5 , or $6-7$ & $\begin{array}{l}11-15-100 \\
\text { ('many') }\end{array}$ & $\begin{array}{l}\text { Microreticulate } \\
\text { (Bayer, 2003) }\end{array}$ & $\begin{array}{l}\text { Petals thin, crumpled } \\
\text { in bud; } \\
\text { stamens numerous }\end{array}$ \\
\hline Ochnaceae & $\begin{array}{l}\text { Rosids } \\
\text { Malphighiales }\end{array}$ & $2-15$ & $\begin{array}{l}5 \text { or } 10 \text { or } \\
11-100\end{array}$ & $\begin{array}{l}\text { Striate (Ferreira de Sousa } \\
\text { et al., 2020) }\end{array}$ & $\begin{array}{l}\text { Style gynobasic } \\
\text { (Bayer, 2003) }\end{array}$ \\
\hline Paracryphiaceae & $\begin{array}{l}\text { Asterids } \\
\text { Paracryphiales }\end{array}$ & $8-15$ & $8-11$ & $\begin{array}{l}\text { Reticulate } \\
\text { (Dickison and Baas, 1977) }\end{array}$ & $\begin{array}{l}\text { Only } 4 \text { tepals, triplo- } \\
\text { steminous }\end{array}$ \\
\hline Pentadiplandraceae & $\begin{array}{l}\text { Rosids } \\
\text { Brassicales }\end{array}$ & $3-5$ & $9-13$ & $\begin{array}{l}\text { Reticulate, spheroidal to } \\
\text { oblate }\end{array}$ & $\begin{array}{l}\text { Pollen shape } \\
\text { (Bayer and Appel, 2003) }\end{array}$ \\
\hline Rutaceae & $\begin{array}{l}\text { Rosids } \\
\text { Sapindales }\end{array}$ & $\begin{array}{l}(1-3) \text { or } 4-5 \\
(-100)\end{array}$ & $\begin{array}{l}2-5 \text { or } 8 \text { or } 10 \\
\text { or } 20-60\end{array}$ & $\begin{array}{l}\text { Reticulate to micro-retic- } \\
\text { ulate (Fernanda Vitorete } \\
\text { and Custódio Gasparino, } \\
\text { 2018) }\end{array}$ & $\begin{array}{l}\text { Obdiplosteminous } \\
\text { (Kubitzki et al., 2011) }\end{array}$ \\
\hline Sapindaceae & $\begin{array}{l}\text { Rosids } \\
\text { Sapindales }\end{array}$ & $(2-) 3(-8)$ & $\begin{array}{l}4-5(-6) \\
\text { (rarely) or } \\
8 \text { or } 10 \text { or } \\
11-100\end{array}$ & $\begin{array}{l}\text { Verrucate, striate, micro- } \\
\text { reticulate, granular colpus } \\
\text { membrane (Muller and } \\
\text { Leenhouts, 1976). }\end{array}$ & $\begin{array}{l}\text { Carpels usually } 3 \text { or } 2 \text {; } \\
\text { granular colpus mem- } \\
\text { brane }\end{array}$ \\
\hline Salicaceae & $\begin{array}{l}\text { Rosids } \\
\text { Malphighiales }\end{array}$ & $2-10$ & $1-2-30-60$ & $\begin{array}{l}\text { Reticulate to microreticu- } \\
\text { late (Keeting, 1973) }\end{array}$ & Stamens usually many \\
\hline Aizoaceae & $\begin{array}{l}\text { Asterids } \\
\text { Caryophyllales }\end{array}$ & 1-5 -many & $\begin{array}{l}(3-) 4-5 \\
\text { or } 8-10 \text { or } \\
15-200\end{array}$ & $\begin{array}{l}\text { Pollen scabrate } \\
\text { (Perveen and Qaiser 2000) }\end{array}$ & Pollen ornamenation \\
\hline Aquifoliaceae & Asterids & $(2-) 4-6(-24)$ & 4 or $7-8(-12)$ & Clavate (Lobreau, 1969) & $\begin{array}{l}\text { Stamens alternate with } \\
\text { petals; Pollen ornamen- } \\
\text { tation }\end{array}$ \\
\hline Ericaceae & $\begin{array}{l}\text { Asterids } \\
\text { Ericales }\end{array}$ & $(2-) 4-5(-10)$ & $\begin{array}{l}5 \text { (rarely) or } \\
8-10\end{array}$ & $\begin{array}{l}\text { Microrugulate, fossulate to } \\
\text { sometimes perforate } \\
\text { (Hoffman, 2018) }\end{array}$ & $\begin{array}{l}\text { Corolla usually synpet- } \\
\text { alous; pollen shed in } \\
\text { tedrads } \\
\text { (Stevens et al., 2004b) }\end{array}$ \\
\hline $\begin{array}{l}\text { Lecythidaceae } \\
\text { [Scytopetalaceae] }\end{array}$ & $\begin{array}{l}\text { Asterids } \\
\text { Ericales }\end{array}$ & $3-8$ & $(10-) 20-240$ & $\begin{array}{l}\text { Microreticulate with } \\
\text { duplibaculate muri } \\
\text { (Appel, 1996) }\end{array}$ & $\begin{array}{l}\text { Calyx synsepalous, } \\
\text { colpus membrane } \\
\text { granular; pollen subob- } \\
\text { late to spheroidal }\end{array}$ \\
\hline
\end{tabular}


Table 1. Continued

\begin{tabular}{l|l|l|l|l|l}
\hline \hline & \multicolumn{1}{|c|}{ Affinity } & Carpel number & \multicolumn{1}{|c|}{$\begin{array}{l}\text { Stamen } \\
\text { number }\end{array}$} & \multicolumn{1}{|c|}{ Pollen ornamentation } & \multicolumn{1}{|c}{$\begin{array}{c}\text { Morphological } \\
\text { differences }\end{array}$} \\
\hline $\begin{array}{l}\text { Lennoaceae } \\
\text { alternately place } \\
\text { in Boraginaceae] }\end{array}$ & Asterids & $6-14$ & $5-10$ & $\begin{array}{l}\text { Microreticulate or } \\
\text { punctate (Yatskievych } \\
\text { and Zavada, 1984) }\end{array}$ & $\begin{array}{l}\text { Pollen oblate; stamens } \\
\text { epipetalous (Yatskievych } \\
\text { and Mason, 1986) }\end{array}$ \\
\hline Marcgraviaceae & $\begin{array}{l}\text { Asterids } \\
\text { Ericales }\end{array}$ & $2-8$ & $3-40$ & $\begin{array}{l}\text { Microreticulate to reticu- } \\
\text { late (Lens et al., 2005) }\end{array}$ & $\begin{array}{l}\text { Colpus membrane } \\
\text { granulate }\end{array}$ \\
\hline Primulaceae & $\begin{array}{l}\text { Asterids } \\
\text { Ericales }\end{array}$ & 5 & $(3-) 5(-9)$ & $\begin{array}{l}\text { Reticulate to } \\
\text { microreticulate (Nowicke } \\
\text { and Skvarla, 1976) }\end{array}$ & $\begin{array}{l}\text { Corolla sympetalous } \\
\text { (Anderberg, 2004) }\end{array}$ \\
\hline Sapotaceae & $\begin{array}{l}\text { Asterids } \\
\text { Ericales }\end{array}$ & $(2-) 4-14(-30)$ & $4-15$ & $\begin{array}{l}\text { Psilate to microreticulate } \\
\text { (Harley, 1991) }\end{array}$ & $\begin{array}{l}\text { Androecial sympetalous; } \\
\text { pollen prolate, rounded } \\
\text { at poles }\end{array}$ \\
\hline Sarraceniaceae & $\begin{array}{l}\text { Asterids } \\
\text { Ericales }\end{array}$ & 3 or 5 5 -) & $(10-) 50-100$ & $\begin{array}{l}\text { (Thanikaimoni and } \\
\text { Vasanthy, 1972) }\end{array}$ & $\begin{array}{l}\text { (3) } \text { tolpate rather } \\
\text { than colporate }\end{array}$ \\
\hline Styracaceae & $\begin{array}{l}\text { Asterids } \\
\text { Ericales }\end{array}$ & $(5-) 8-10(-20)$ & $(5-) 8-10(-20)$ & $\begin{array}{l}\text { Rugulate to } \\
\text { micro-reticulate (Morton } \\
\text { and Dickison, 1992) }\end{array}$ & $\begin{array}{l}\text { Stamens usu. twice or } \\
\text { equal the corolla } \\
\text { lobes (Fritsch, 2004) }\end{array}$ \\
\hline Theaceae & $\begin{array}{l}\text { Asterids } \\
\text { Ericales }\end{array}$ & $(2-) 3-5(-10)$ & $\begin{array}{l}5 \text { or 10 or 15 } \\
\text { or 16-100 }\end{array}$ & $\begin{array}{l}\text { Microreticulate } \\
\text { (Li et al., 2010) }\end{array}$ & $\begin{array}{l}\text { Styles usually as many } \\
\text { as carpels; stamens 20+ } \\
\text { (Stevens et al., 2004a) }\end{array}$ \\
\hline
\end{tabular}

moved northward through new climate zones and collided with Eurasia (e.g. Ding et al., 2017; Klaus et al., 2016), facilitating new competition from the introduction of Laurasian taxa. Additional collections leading to future recognition of Singpuria-type flowers in the Deccan cherts (or elsewhere) should provide the additional data needed to test our hypotheses about this flower's affinities and evolutionary history.

\section{ACKNOWLEDGEMENTS}

We thank Walter Judd and Louis P. Ronse de Craene for helpful discussions, and Alexei Herman and an additional reviewer for helpful comments on the initial manuscript. Terry Lott provided helpful technical assistance. This work was supported in part by National Science Foundation grants to S.R. Manchester (EAR 1338285) and S.Y. Smith (EAR 1338295).

\section{REFERENCES}

Anderberg, A.A., 2004. Primulaceae. In: Kubitzki, K. (ed.), The Families and Genera of Vascular Plants VI, Flowering Plants, Dicotyledons. Springer, Berlin, pp. 313-319.

Appel, O., 1996. Morphology and systematics of the Scytopetalaceae. Botanical Journal of the Linnean Society 121(3), 207-227.

Arrington, J.M., Kubitzki, K., 2003. Cistaceae. In: Kubitzki, K., Bayer, C. (eds), The Families and Genera of Vascular Plants V, Flowering Plants, Dicotyledons. Springer, Berlin, pp. 62-70.

Bayer, C., 2003. Muntingiaceae. In: Kubitzki, K., Bayer, C. (eds), The Families and Genera of Vascular Plants V, Flowering Plants, Dicotyledons. Springer, Berlin, pp. 315-319.
Bayer, C., Appel, O., 2003. Pentadiplandraceae. In: Kubitzki, K., Bayer, C. (eds). The Families and Genera of Vascular Plants V, Flowering Plants. Dicotyledons. Springer, Berlin, pp. 329-331.

Bayer, C., Kubitzki, K., 2003. Malvaceae. In: Kubitzki, K., Bayer, C. (eds), The Families and Genera of Vascular Plants V, Flowering Plants, Dicotyledons. Springer, Berlin, pp. 225-311.

Bhowal, M., Sheikh, M.T., 2004. Baccatocarpon sharmae gen. et. sp. nov. - A petrified dicot baccate fruit from the Deccan intertrappean beds of Singhpur, Madhya Pradesh, India. Trends in Life Science 19, 25-22.

Bove, C.P., Melhem, T.S., 2000: Humiriaceae Juss. World Pollen and Spore Flora 21, 1-35.

Chanderbali, A.S., Berger, B.A., Howarth, D.G., Soltis, D.E., Soltis, P.S., 2017. Evolution of floral diversity: genomics, genes and gamma. Philosophical transactions of the Royal Society of London. Series B, Biological sciences, 372(1713), 20150509; DOI: https://doi.org/10.1098/rstb.2015.0509

Chitaley, S.D., Patil, G.V., 1973. Sahniocarpon harrisii gen. et sp. nov. from the Mohgaonkalan beds of India. The Palaeobotanist 20(1), 288-292.

Chitaley, S.D., Sheikh, M.T., 1971. An infected grain from the Deccan Intertrappean Cherts of Mohgaonkalan. Journal of the Indian Botanical Society 50, 137-142.

Chitaley, S.D., Sheikh, M.T., 1973. A ten locular petrified fruit from the Dcccan Intertrappean series of India. The Palaeobotanist 20(3), 297-299.

Christensen, P.B., 1986. Pollen morphological studies in the Malvaceae. Grana 25, 95-117.

Civeyrel, L., Leclercq, J., Demoly, J.P., Agnan, Y., Quebre, N., Pélissier, C., Otto, T., 2011. Molecular systematics, character evolution, and pollen morphology of Cistus and Halimium (Cistaceae). Plant Systematics and Evolution 95(1-4), 23-54. 
Daly, D.C., Harley, M.M., Martínez-Habibe, M.-C., Weeks, A., 2011. Burseraceae. In: Kubitzki, K. (ed.), The Families and Genera of Vascular Plants $\mathrm{X}$, Flowering Plants, Eudicots. Springer, Berlin, pp. 76-104.

Dickison, W.C., Baas, P., 1977. The morphology and relationships of Paracryphia (Paracryphiaceae). Blumea 23(2), 417-438.

Dickison, W.C., Nowicke, J.W., Skvarla, J.J., 1982. Pollen morphology of the Dilleniaceae and Actinidiaceae. American Journal of Botany 69(7), 1055-1073.

Ding, L., Maksatbek, S., Cai, F., Wang, H., Song, P., Ji, W., Xu, Q., Zhang, L., Muhammad, Q., Upendra, B., 2017. Processes of initial collision and suturing between India and Asia. Science China Earth Sciences 60(4), 635-651.

Fernanda Vitorete, D., Custódio Gasparino, E., 2018. Pollen morphology of Rutaceae from Brazilian forest fragments. Palynology 42(1), 43-54.

Ferreira De Sousa, H.C., Gonçalves-Esteves, V., Trovó, M., Mendonça, C.B.F., 2020. Palynology of Ochnaceae from the Itatiaia National Park, Brazil. Feddes Repertorium 131(2), 93-100.

Fritsch, P.W. 2004. Styracaceae. In: Kubitzki, K. (ed.), The Families and Genera of Vascular Plants VI, Flowering Plants, Dicotyledons. Springer, Berlin, pp. 434-442.

Halbritter, H., Ulrich, S., Grímsson, F., Weber, M., Zetter, R., Hesse, M., Buchner, R., Svojtka, M., Frosch-Radivo, A., 2018. Illustrated pollen terminology. Second ed., Springer, Cham, Switzerland. $483 \mathrm{pp}$.

Harley, M.M., 1991. The pollen morphology of the Sapotaceae. Kew Bulletin 46(3), 379-491.

Harley, M.M., Song, U., Banks, H.I., 2005. Pollen morphology and systematics of Burseraceae. Grana 44(4), 282-299.

Hofmann, C.C., 2018 Light and scanning electron microscopic investigations of pollen of Ericales (Ericaceae, Sapotaceae, Ebenaceae, Styracaceae and Theaceae) from five lower and mid-Eocene localities. Botanical Journal of the Linnean Society 187(4), 550-578.

Horn, J.W., 2007. Dilleniaceae. In: Kubitzki, K. (ed.), The Families and Genera of Vascular Plants IX, Flowering Plants Eudicots. Springer, Berlin, pp. 132-154.

Ibe, R.A., Leis, R.A., 1979. Pollen morphology of the Anacardiaceae of northeastern North America. Bulletin of the Torrey Botanical Club 106(2), 140-144.

Judd, W.S., Campbell, C.S., Kellogg, E.A., Stevens, P.F., Donoghue, M.J., 2016. Plant systematics: A Phylogenetic Approach, $4^{\text {th }}$ edition. Sinauer Assoc. Inc., Sunderland, MA.

Kapgate, D.K., 2005. Megafloral analysis of intertrappean sediments with focus on diversity and abundance of flora of Mohgaonkalan, Mandla and adjoining areas of Madhya Pradesh. Gondwana Geological Magazine 20, 31-46.

Kapgate, D.K., Patil, S.P., Ilamkar, N.P., Ramteke, D.D., 2007. Investigation of a new petrified trilocular fruit from the Deccan Intertrappean Series of Mohgaonkalan, M.P. In: Trivedi, P.C. (ed.), Palaeobotany to Modern botany. Pointer Publications, Jaipur, pp. 43-48.

Kapgate, D.K, Manchester, S.R., Stuppy, W., 2017. Oldest fruit of Phyllanthaceae from the Deccan Intertrappean Beds of Singpur, Madhya Pradesh, India. Acta Palaeobotanica 57(1), 33-38.

Kapgate, V.D., Kapgate, D.K., Sheikh, M.T., 2006. Chenopodianthus, a fossil flower genus from the Deccan Intertrappean Beds of India. Geophytology $36,27-34$.

Kapgate, V.D., Kapgate, D.K., Sheikh, M.T., 2009. Araliaceous fossil flower from the Deccan Intertrappean beds of Madhya Predesh, India. The Palaeobotnist 58, 67-74.

Kar, R.K., Ambwani, K., Sahni, A., Sharma, P., 2003. Unisexual flowers from the Deccan Intertrappean Bed of Madhya Pradesh, India. The Palaeobotanist 52, 73-79.

Kebert. 2014-2020. Floral diagram generator, http:// kvetnidiagram.8u.cz/index_en.php

Keeting, R.C., 1973. Pollen morphology and relationships of the Flacourtiaceae. Annals of the Missouri Botanical Garden 60, 273-305.

Klaus, S., Morley, R.J., Plath, M., Zhang, Y.P., Li, J.T., 2016. Biotic interchange between the Indian subcontinent and mainland Asia through time. Nature Communications 7(1), 1-6.

Kubitzki, K., Kallunki, J.A., Duretto, M., Wilson, P.G., 2011. Burseraceae. In: Kubitzki, K. (ed.), The Families and Genera of Vascular Plants X, Flowering Plants, Eudicots. Springer Heidelberg, pp. 276-356.

Lens, F., Dressler, S., Vinckier, S., Janssens, S., Dessein, S., Van Evelghem, L., Smets, E., 2005. Palynological variation in balsaminoid Ericales. I. Marcgraviaceae. Annals of Botany 96(6), 1047-1060.

Li, T.Q., Cao, H.J., Kang, M.S., Zhang, Z.X., Zhao, N., Zhang, H., 2010. Pollen flora of China woody plants by SEM. Beijing: Science Press; 1233 pp. (in Chinese).

Lobreau, D.A., 1969. Limites de l'ordre des Celastrales d'apres le pollen. Pollen et spores 11, 499-555.

Manchester, S.R., Kapgate, D.K., Ramteke, D.D., Patil, S.P., Smith, S.Y., 2019. Morphology and anatomy of the angiosperm fruit Baccatocarpon, incertae sedis, from the Maastrichtian Deccan Intertrappean Beds of India. Acta Palaeobotanica 59(2), 241-250.

Manchester, S.R., Kapgate, D.K., Patil, S.P., Ramteke, D., Matsunaga, K., Smith, S.Y., 2020. Morphology and affinities of Pantocarpon fruits (cf. Apiales: Torricelliaceae) from the Maastrichtian Deccan Intertrappean Beds of central India. International Journal of Plant Sciences 181(4), 443-451. DOI: https://doi.org/10.1086/706856.

Matsunaga, K.S., Smith, S.Y., Manchester, S.R., Kapgate, D., Ramteke, D., Garbout, A., VillarragaGómez, H., 2018. Reinvestigating an enigmatic Late Cretaceous monocot: morphology, taxonomy, and biogeography of Viracarpon. PeerJ 6, e4580; DOI: $10.7717 /$ peerj.4580. 
Morton, C.M., Dickison, W.C., 1992. Comparative pollen morphology of the Styracaceae. Grana 31(1), 1-15.

Muller, J., Leenhouts, P.W., 1976. A general survey of pollen types in Sapindaceae in relation to taxonomy. In: Ferguson, I.K., Muller, J., (eds), The evolutionary significance of the exine. Linnean Society Symposium 18-20 September 1974, Kew, UK., pp. 407-495.

Nandeshwar, M.P., Narkhede, S.D., 2016. A new petrified drupaceous fruit from the Deccan Intertrappean Beds of Singhpur, Madhya Pradesh. In: Proceedings National Seminar on Recent Trends in Life Sciences and Materials Science. Gurukul International Multidisciplinary Research Journal, 42-47.

Nandeshwar, M.P., Narkhede, S.D., 2017. Report of a new fossil dicotyledonous seed Singhpurospermum deccanii gen et, sp. nov. from the Deccan Intertrappean Beds of Singhpur, Madhya Pradesh, India. International Journal of Advance and Innovative Research 4(4), 72-75.

Nowicke, J.W., Skvarla, J.J., 1976. Pollen morphology and the relationship of the Plumbaginaceae, Polygonaceae, and Primulaceae to the order Centrospermae. Smithsonian Contributions to Botany 37. Smithsonian Institution Press, Washington, D.C.

Oswald, W.W., Doughty, E.D., Néeman, G., Néeman, R., Ellison, A.M., 2011. Pollen morphology and its relationship to taxonomy of the genus Sarracenia (Sarraceniaceae). Rhodora 113(955), 235-251.

Pell, S.K., Mitchell, J.D., Miller, A.J., Lobova, T.A., 2011. Anacardiaceae. In: Kubitzki, K. (ed.), The Families and Genera of Vascular Plants X, Flowering Plants, Eudicots. Springer Heidelberg, pp. 7-50.

Perveen, A., Grafström, E., El-Ghazaly, G., 2004. World Pollen and Spore Flora 23. Malvaceae Adams. Subfamilies: Grewioideae, Tilioideae, Brownlowioideae. Grana 43, 129-155.

Perveen, A., Qaiser, M., 2000. Pollen Flora of Pakistan-XIX. Aizoaceae. Turkish Journal of Botany 24(1), 29-33.

Ronse De Craene, L., 2010. Floral diagrams and aid to understanding flower morphology and evolution. Cambridge University Press, Cambridge.

Sahni, B., 1943. Indian silicified plants-2. Enigmocarpon parijai silicified fruit from the Deccan with a review of fossil history of the Lythraceae. Proceedings of the Indian Academy of Sciences 17 B(3), 59-96.

Samant, B., Mohabe, D.M., Kapgate, D.K., 2008. Palynofloral record from Singpur Intertrappean, Chhindwara District, Madhya Pradesh: Implication for Late Cretaceous stratigraphic correlation and resolution. Journal of the Geological Society of India 71, 851-858.

Satabié, B., 1974. Contribution de la palynologie à l'étude des Irvingiacées d'Afrique Tropicale. Adansonia. ser. 2, 14(2), 277-289.

Seetharam, Y.N., Maheshwari, J.K., 1986. Scanning electron microscopic studies on the pollen of some
Clusiaceae. Proceedings India Academy of Sciences (Plant Sciences) 96(3), 217-226.

Sheikh, M.T., Bhowal, M., 2003. A dicot seed Ramakonospermus singhpurii from the Intertrappean beds of Singhpur, Madhya Pradesh, India. The Botanique 12(1), 84-87.

Shukla, V.B., 1944. On Sahnianthus, a new genus of petrified flowers from the intertrappean beds at Mohgaon Kalan in the Deccan and its relation with the fruit Enigmocarpon parijai Sahni from the same locality. Proceedings of the Natural Science Academy, India, 14, 1-39.

Smith, S.Y., Manchester, S.R., Samant, B., Mohabey, D.M., Wheeler, E.A., Baas, P., Kapgate, D., Srivastava, R., Sheldon, N.D., 2015. Integrating paleobotanical, paleosol, and stratigraphic data to study critical transitions: a case study from the Late Cretaceous-Paleocene of India. The Paleontological Society Papers 21, 137-166.

Soltis, D., Soltis, P., Endress, P., Chase, M.W., Manchester, S.R., Judd, W., Majure, L., Mavrodiev, E., 2018. Phylogeny and evolution of the angiosperms: revised and updated edition. University of Chicago Press, Chicago. 580 pp.

Sprain, C.J., Renne, P.R., Vanderkluysen, L., Pande, K., Self, S., Mittal, T., 2019. The eruptive tempo of Deccan volcanism in relation to the CretaceousPaleogene boundary. Science 363, 66-870.

Stevens, P.F., 2004. Clusiaceae-Guttiferae. In: Kubitzki, K. (ed.), The Families and Genera of Vascular Plants VI, Flowering Plants, Dicotyledons. Springer, Berlin, pp. 48-66.

Stevens, P.F., Dressler, S., Weitzman, A.L., 2004a. Theaceae. In: Kubitzki, K. (ed.), The Families and Genera of Vascular Plants VI, Flowering Plants, Dicotyledons. Springer, Berlin, pp. 463-471.

Stevens, P.F., Luteyn, J., Oliver, E.G.H., Bell, T.L., Brown, E.A., Crowden, R.K., George, A.S., Jordan, G.J., Ladd, P., Lemson, K., McLean, C.B. 2004b. Ericaceae. In: Kubitzki, K. (ed.), The Families and Genera of Vascular Plants VI, Flowering Plants, Dicotyledons. Springer, Berlin, pp. 145-194.

Thanikaimoni, G., Vasanthy, G., 1972. Sarraceniaceae: palynology and systematics. Pollen et Spores 14, 143-155.

Ukraintseva, V.V., 1993. Pollen Morphology of the Family Cistaceae in relation to its taxonomy. Grana 32(S2), 33-36.

Yatskievych, G., Mason, C.T., Jr, 1986. A revision of the Lennoaceae. Systematic Botany 11, 531-548.

Yatskievych, G., Zavada, M., 1984. Pollen morphology of Lennoaceae. Pollen et Spores 26, 19-30.

Watson, L., Dallwitz, M.J., 1992 onwards. The families of flowering plants: descriptions, illustrations, identification, and information retrieval. Version: 28th August 2020. delta-intkey.com.

Wheeler, E.A., Srivastava, R., Manchester, S.R., Baas, P., 2017. Surprisingly modern Latest Cretaceous-earliest Paleocene woods of India. International Association of Wood Anatomists Journal 38(4), 456-542. 